\title{
Evaluation of serum levels of IL-6, IL-10, and TNF- $\alpha$ in alopecia areata patients: A systematic review and meta-analysis
}

\author{
Shirin Torkestani ${ }^{1}$, Hamid Moghimi ${ }^{1}$, Reza Farsiabi ${ }^{2}$, Salman Khazaei ${ }^{3,{ }^{*}}$, Mohammad Mahdi Eftekharian ${ }^{4}$, \\ Esmaeil Dalvand ${ }^{1}$
}

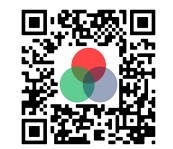

Use your smartphone to scan this QR code and download this article

${ }^{1}$ Department of Medical Immunology,

Faculty of Medicine, Hamadan

University of Medical Sciences,

Hamadan, Iran

${ }^{2}$ Department of Medical Biochemistry, Faculty of Medicine, Hamadan

University of Medical Sciences,

Hamadan, Iran

${ }^{3}$ Research Center for Health Sciences,

Hamadan University of Medical

Sciences, Hamadan, Iran

${ }^{4}$ Neurophysiology Research Center, Hamadan University of Medical

Sciences, Hamadan, Iran

\section{Correspondence}

Salman Khazaei, Research Center for Health Sciences, Hamadan University of Medical Sciences, Hamadan, Iran

Email: salman.khazaei61@gmail.com

\section{History}

- Received: Aug 30, 2021

- Accepted: Sep 29, 2021

- Published: Oct 31, 2021

DOI : 10.15419/bmrat.v8i10.702

\section{Check for updates}

\section{Copyright}

(c) Biomedpress. This is an openaccess article distributed under the terms of the Creative Commons Attribution 4.0 International license.

\begin{abstract}
Background: The role of pro and anti-inflammatory cytokines in autoimmune and inflammatory disorders has always been discussed; several studies have assayed serum levels of Interleukin-6 (IL-6), Tumor Necrosis Factor- $\alpha$ (TNF- $\alpha$ ), and Interleukin-10 (IL-10) in alopecia areata (AA) patients. Determining the cytokine profile of AA patients will help us understand the role of the immune system in the pathogenesis of AA. Due to a lack of comprehensive studies in this regard, we have performed this meta-analysis to evaluate previously mentioned cytokines in AA patients. Method: We explored PubMed, Scopus, web of science, and ScienceDirect databases for research without a limited start date until May 2021. A number of 1098 studies were found in the initial database search and reference lists of relevant studies; 16 studies were finally included in the meta-analysis. Differences in the levels of IL-6, TNF- $\alpha$, and IL-10 in sera of controls and patients were pooled as standardized mean differences. A random-effects model was used in this study. Begg's and Egger's tests were carried out to investigate publication bias. Results: 16 studies were included. This study found significantly elevated levels of IL- 6 in AA patients compared to healthy subjects (SMD $=1.57,95 \% \mathrm{Cl} 0.17$ to 2.97 ). The levels of TNF- $\alpha$ were also significantly higher in the serum of AA patients (SMD $=2.05,95 \% \mathrm{Cl} 0.98$ to 3.13$)$. Though IL-10 levels were lower in serum of AA patients, this difference was not significant ( $S M D=-0.22,95 \% \mathrm{Cl}-0.95$ to 0.50). Conclusion: According to the crucial role of cytokines in autoimmunity, alternation in the serum levels of cytokines in AA patients was not unexpected; our study shows that cytokines might have an essential role in the pathogenesis of AA, though further studies are needed to clarify the exact role of cytokines in the emergence and persistence of AA.
\end{abstract}

Key words: Alopecia areata, Interleukin-10, Interleukin-6, Tumor Necrosis Factor- $\alpha$

\section{INTRODUCTION}

Alopecia areata (AA) is an autoimmune, inflammatory, and nonscarring disease that leads to hair loss on the body or scalp. It has two main subgroups: Alopecia Totalis (AT) and Alopecia Universalis (AU). The former includes those patients with a total absence of terminal scalp hair, and the latter include those patients with complete loss of terminal scalp and body hair ${ }^{1}$. Few studies of prevalence and incidence have reported a $0.1-0.2 \%$ incidence with a lifetime risk of $1.7 \%$ equally in men and women. Furthermore, about $2 \%$ of new dermatology patients in the United States and the United Kingdom suffer from $\mathrm{AA}^{\mathbf{1 , 2}}$.

AA mostly shows itself through a sudden hair loss in well-demarcated sites. The area is commonly an oval or round patch of alopecia, and it can be numerous or isolated. Previous documents noted that though the most common complication of this disease is the involvement of the scalp hair, it may affect body hair such as underarm hair, beard, eyelashes, eyebrows, and pubic hair ${ }^{2-5}$.

Circumstances such as infection and tissue injury can result in inflammation ${ }^{\mathbf{6}}$. The inflammatory state can represent itself by elevated inflammatory cytokines such as IL-6, TNF $\alpha$, and CRP, and a decrease of i-inflammatory cytokines such as IL-10 ${ }^{7,8}$. An inappropriate autoimmune response may stem from a chronic inflammatory condition ${ }^{9}$. It has been demonstrated that defects in cytokines and their signaling can lead to autoimmune diseases ${ }^{10}$. It is confirmed that cytokines play a crucial role in the $\mathrm{CD} 4^{+}$ $\mathrm{T}$ cell-mediated inflammatory response in $\mathrm{AA}^{\mathbf{1 1}}$.

IL- 6 and TNF- $\alpha$ are two inflammatory cytokines that play an important role in different inflammatory disorders like rheumatoid arthritis and psoriasis ${ }^{12,13}$. Recent studies on the serum levels of these two inflammatory cytokines in AA patients have shown contradictory results ${ }^{11,14,15}$. Furthermore, recent studies on the serum levels of IL-10 in AA patients have shown paradoxical results, including both in- 
creasing and decreasing ${ }^{16,17}$.

Several studies have explored the links between AA and IL-6, IL-10 and AA and TNF- $\alpha^{11,16,18}$. Due to inconsistent results and the lack of comprehensive studies, we performed a meta-analysis to determine the role of cytokines in AA and to provide more evidence for future related studies.

\section{METHODS}

\section{Search method}

PubMed, Scopus, Web of Science, and ScienceDirect were searched following the Preferred Reporting of Items for Systematic Reviews and Meta-Analyses (PRISMA) guidelines ${ }^{19}$. We used the following keywords: 'Alopecia areata' and 'Interleukin-10' or 'IL-10', 'Interleukin-6' or 'IL-6', 'TNF- $\alpha$ ' or 'tumor necrosis factor-alpha'. The reference lists of relevant studies were also reviewed. No restriction for the time was applied, and we searched databases from inception to May 2021.

\section{Exclusion and inclusion criteria}

Only English articles were included in this study. The title and abstract of identified documents were reviewed to select relevant articles, and in case of doubt, full texts were reviewed. Duplicate studies and irrelevant studies such as review articles, case series, case reports, animal studies, genetic studies, and studies that did not report sufficient data were excluded.

\section{Data Extraction and Quality Assessment}

We extracted the following information from the included studies: first author, publication year, country, disease type, measurement method, age of patients and healthy controls, and serum levels of IL-10, IL-6, or TNF- $\alpha$. If the mean and SD values were not mentioned in the text of manuscripts, we estimated them from given data such as median, range, and IQR.

The risk of bias was evaluated by NIH Quality Assessment Tools ${ }^{20}$. Quality assessment was performed by two authors.

\section{Statistical analysis}

Random-effects meta-analysis was used to estimate standardized mean difference (SMD). The publication bias was assessed using Begg's and Egger's tests ${ }^{21}$. The heterogeneity of results between studies was checked by $\mathrm{I}^{2}$ statistic $^{22}$, STATA/SE 11.0, and was utilized for statistical analysis (Stata-Corp, College Station, TX, USA).

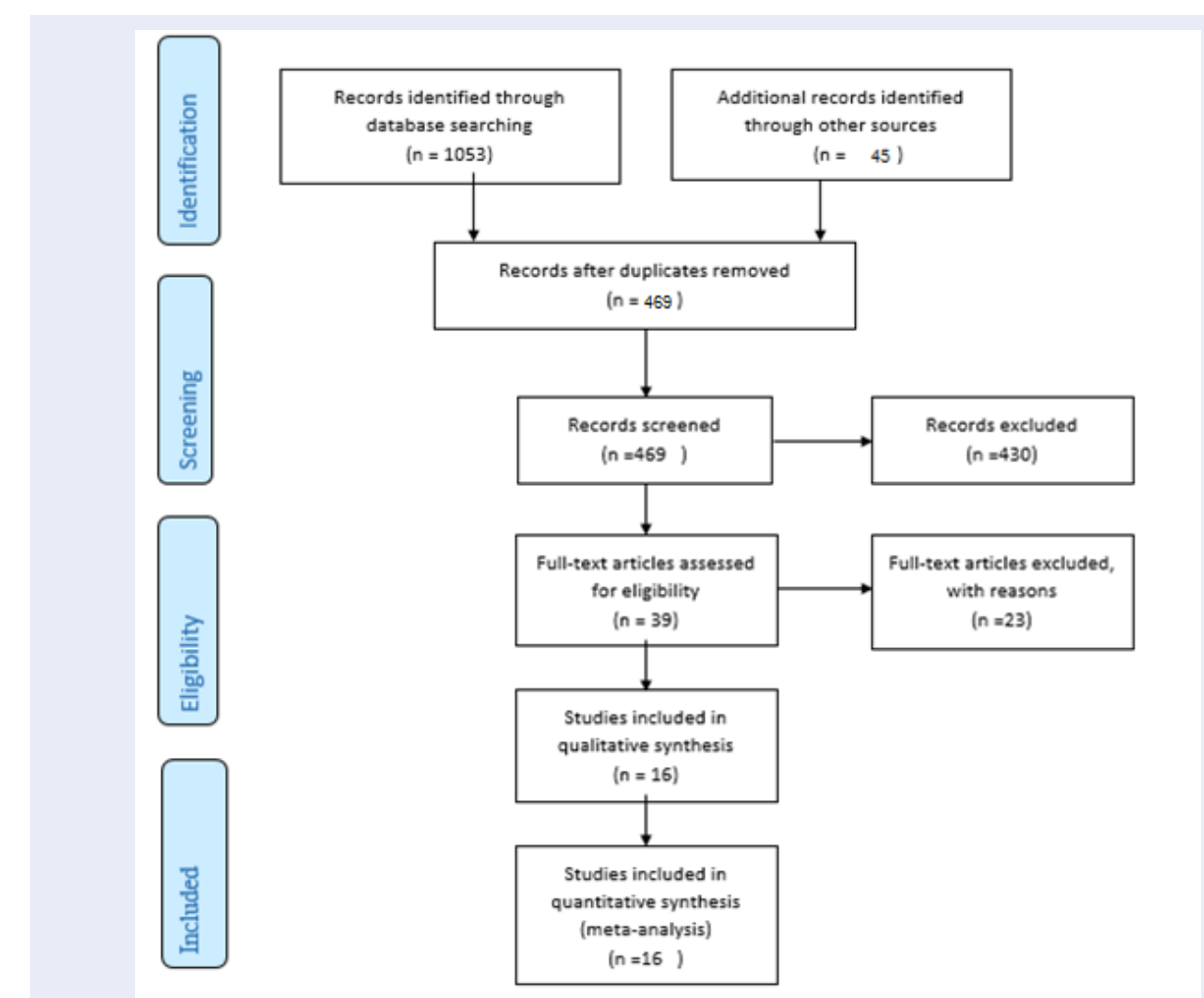


Table 1: Characteristics of included studies in the analysis of IL- 6 serum levels

\begin{tabular}{|c|c|c|c|c|c|c|c|c|}
\hline First author & Year & Country & $\begin{array}{l}\text { Subgroups/Severity } \\
\text { of disease }\end{array}$ & $\begin{array}{c}\text { Number of } \\
\text { cases/ healthy } \\
\text { control }\end{array}$ & IL-6 levels in patients & $\begin{array}{c}\text { IL-6 levels in } \\
\text { healthy controls }\end{array}$ & $\begin{array}{c}\text { IL-6 } \\
\text { measurement }\end{array}$ & $\begin{array}{c}\text { Ageof } \\
\text { cases/controls }\end{array}$ \\
\hline Atwa et al. ${ }^{23}$ & 2016 & Egypt & $\begin{array}{l}\text { Single patch AA, Multiple } \\
\text { AA, Ophiasis, AU, AT }\end{array}$ & $47 / 40$ & $17.18 \pm 3.08$ & $4.59 \pm 1.66$ & ELISA & $\begin{aligned} 22.68 & \pm 8.62 / 23.22 \\
& \pm 8.95\end{aligned}$ \\
\hline Bilgic et al. ${ }^{11}$ & 2015 & Turkey & Mild, Moderate, Severe & $40 / 40$ & $25.70 \pm 9.7$ & $11.80 \pm 9.2$ & ELISA & $\begin{array}{c}28.7 \pm 7.9 / \\
30.5 \pm 8.4\end{array}$ \\
\hline $\begin{array}{l}\text { Ataseven } \\
\text { et al. }{ }^{14}\end{array}$ & 2011 & Turkey & Not mentioned & $43 / 30$ & $1.36 \pm 0.39$ & $1.44 \pm 0.56$ & ELISA & $\begin{array}{r}23.42 \pm 11.41 / \\
26.73 \pm 4.70\end{array}$ \\
\hline $\begin{array}{l}\text { Tomaszewska } \\
\text { et al. }{ }^{\mathbf{2 4}}\end{array}$ & 2020 & Poland & Patchy, and Sever & $33 / 30$ & $121.38 \pm 31.01$ & $75.26 \pm 21.15$ & ELISA & $\begin{array}{c}18.64 \pm 8.56 / \\
19.95 \pm 13.08\end{array}$ \\
\hline $\begin{array}{l}\text { Barahmani } \\
\text { et al. }{ }^{18}\end{array}$ & 2009 & USA & $\begin{array}{c}\text { Transient AA, Persistent } \\
\text { AA, AT or AU }\end{array}$ & $269 / 18$ & $\begin{array}{c}\text { AAP: } 1.20^{*} \text { AAT: } 1.50^{*} \\
\text { AT / AU: } 1.30^{*}\end{array}$ & $0.69^{*}$ & $\begin{array}{c}\text { Mutli-analyte } \\
\text { proteome } \\
\text { array }\end{array}$ & $\begin{array}{c}39 \pm 18.8 / \\
44 \pm 13.6\end{array}$ \\
\hline
\end{tabular}

Abbreviations: AA: Alopecia areata, AU: Alopecia universalis, AT: Alopecia totalis, AAP: persistent alopecia areata, AAT: transient alopecia areata, IL-6: Interleukin-6, *: median 
Table 2: Characteristics of included studies in the analysis of IL-10 serum levels

\begin{tabular}{|c|c|c|c|c|c|c|c|c|}
\hline First author & Year & Country & Subgroups/Severity of disease & $\begin{array}{c}\text { Number of } \\
\text { cases/ healthy } \\
\text { control }\end{array}$ & $\begin{array}{l}\text { IL-10 levels in } \\
\text { patients }\end{array}$ & $\begin{array}{l}\text { IL-10 levels in } \\
\text { healthy controls }\end{array}$ & $\begin{array}{c}\text { IL-10 } \\
\text { measurement }\end{array}$ & $\begin{array}{c}\text { Ageof } \\
\text { cases/controls }\end{array}$ \\
\hline Gautam et al. ${ }^{16}$ & 2019 & India & Localized and Extensive AA & $40 / 40$ & $3.144^{*}$ & $1.050^{*}$ & $\begin{array}{l}\text { Sandwich } \\
\text { ELISA }\end{array}$ & $\begin{array}{c}29.4 \pm 8.3 / 22.6 \pm \\
3.8\end{array}$ \\
\hline Loh et al. ${ }^{25}$ & 2018 & Korea & Patchy, AT/AU, ADTA, Ophiasis & $55 / 15$ & $4.54 \pm 0.001$ & $3.25 \pm 0.071$ & ELISA & $38.16 / 41.17$ \\
\hline Ma et al. ${ }^{17}$ & 2017 & china & $\begin{array}{c}\text { Severe AA in active or stable } \\
\text { phase }\end{array}$ & $100 / 50$ & & 21.20 & ELISA & $\begin{array}{c}\text { Active phase: } 41.2 \\
\pm 13.5, \text { Stable } \\
\text { phase: } 40.9 \pm \\
14.4 / 43.5 \pm 16.1\end{array}$ \\
\hline Ataseven et al. ${ }^{14}$ & 2011 & Turkey & Not mentioned & $43 / 30$ & $5.94 \pm 1.17$ & $6.32 \pm 0.85$ & ELISA & $\begin{array}{c}23.42 \pm 11.41 / \\
26.73 \pm 4.70\end{array}$ \\
\hline Tembhre et al. ${ }^{26}$ & 2013 & India & Extensive AA,AT,AU & $51 / 45$ & $9.47^{\star}$ & $10.47^{*}$ & ELISA & $\begin{array}{c}24.19 \pm 6.69 / 26.42 \\
\quad \pm 4.35\end{array}$ \\
\hline $\begin{array}{l}\text { Barahmani } \\
\text { et al. }{ }^{18}\end{array}$ & 2009 & USA & $\begin{array}{c}\text { Transient AA, Persistent AA, AT } \\
\text { or AU }\end{array}$ & $269 / 18$ & $\begin{array}{l}\text { AAP: } 0.85^{\star} \\
\text { AAT: } 0.90^{\star} \text { AT } \\
\text { / AU: } 0.85^{\star}\end{array}$ & $0.69^{*}$ & $\begin{array}{c}\text { Mutli-analyte } \\
\text { proteome } \\
\text { array }\end{array}$ & $\begin{array}{c}39 \pm 18.8 / 44 \pm \\
13.6\end{array}$ \\
\hline
\end{tabular}

Abbreviations: AA: Alopecia areata, AU: Alopecia universalis, AT: Alopecia totalis, ADTA: acute diffuse and total alopecia, AAP: persistent alopecia areata, AAT: transient alopecia areata, IL-10: Interleukin-10, *: median 
Table 3: Characteristics of included studies in the analysis of TNF- $\alpha$ serum levels

\begin{tabular}{|c|c|c|c|c|c|c|c|c|}
\hline First author & Year & Country & $\begin{array}{c}\text { Subgroups/Severity of } \\
\text { disease }\end{array}$ & $\begin{array}{l}\text { Number of } \\
\text { cases/ healthy } \\
\text { control }\end{array}$ & $\begin{array}{c}\text { TNF-alpha } \\
\text { levels in patients }\end{array}$ & $\begin{array}{l}\text { TNF -alpha } \\
\text { levels in healthy } \\
\text { controls }\end{array}$ & $\begin{array}{l}\text { TNF-alpha } \\
\text { measurement }\end{array}$ & $\begin{array}{c}\text { Age of } \\
\text { cases/controls }\end{array}$ \\
\hline $\begin{array}{l}\text { Kasumagic- } \\
\text { Halilovic etal. }^{27}\end{array}$ & 2011 & $\begin{array}{l}\text { Bosnia and } \\
\text { Herzegovina }\end{array}$ & LAA,AT/AU & $60 / 20$ & $10.31 \pm 1.20$ & $9.59 \pm 0.75$ & ELISA & $35.6 / 32.6^{*}$ \\
\hline $\begin{array}{l}\text { Abdel Halim } \\
\text { et al. }{ }^{28}\end{array}$ & 2018 & Egypt & Multiple patches & $20 / 20$ & $102.44 \pm 16.16$ & $39.03 \pm 13.57$ & Elisa & $\begin{array}{c}28.4 \pm 11.408 / \\
29.02 \pm 13.57\end{array}$ \\
\hline Atwa et al. ${ }^{23}$ & 2016 & Egypt & $\begin{array}{c}\text { Single patch, Multiple } \\
\text { patches, Ophiasis ,AT } \\
\text {,AU }\end{array}$ & $47 / 40$ & $19.94 \pm 3.59$ & $9.95 \pm 2.42$ & ELISA & $\begin{array}{c}22.68 \pm 8.62 / \\
23.22 \pm 8.95\end{array}$ \\
\hline $\begin{array}{l}\text { Abd El-Raheem } \\
\text { et al. }{ }^{29}\end{array}$ & 2020 & Egypt & Mild, Moderate, Severe & $75 / 75$ & $8.8^{*}$ & $1.4^{*}$ & ELISA & $\begin{aligned} 24.8 & \pm 18.6 / 26.3 \\
& \pm 4.328\end{aligned}$ \\
\hline Bilgic et al. 11 & 2015 & Turkey & Mild, Moderate, Severe & $40 / 40$ & $20.60 \pm 6.20$ & $10.20 \pm 7.50$ & ELISA & $\begin{array}{c}28.7 \pm 7.9 / 30.5 \\
\quad \pm 8.4\end{array}$ \\
\hline Loh et al. ${ }^{25}$ & 2018 & Korea & $\begin{array}{l}\text { Patchy, AT /AU, } \\
\text { ADTA), Ophiasis }\end{array}$ & $55 / 15$ & $12.76 \pm 0.003$ & $3.33 \pm 0.011$ & ELISA & 38.16 / 41.17 \\
\hline $\begin{array}{l}\text { A. Alzolibani } \\
\text { et al. }\end{array}$ & 2016 & Saudi Arabia & Patchy persistent & $25 / 26$ & 27.70 & 14.70 & $\begin{array}{l}\text { Sandwich } \\
\text { ELISA }\end{array}$ & $\begin{array}{c}30.2 \pm 8.43 / 32.3 \\
\quad \pm 10.8\end{array}$ \\
\hline Serarslan et al. ${ }^{15}$ & 2020 & turkey & $\begin{array}{c}\text { Patch pattern, Patch } \\
\text { and ophiasis pattern, } \\
\text { AT,AU }\end{array}$ & $36 / 34$ & $113.68 \pm 106.34$ & $121.15 \pm 55.31$ & $\begin{array}{l}\text { sandwich } \\
\text { ELISA }\end{array}$ & $\begin{array}{c}31.33 \pm 9.47 / \\
30.5 \pm 9.11\end{array}$ \\
\hline Teraki et al. ${ }^{31}$ & 1996 & Japan & Localized form & $7 / 7$ & $8.30 \pm 0.90$ & $7.60 \pm 0.20$ & $\begin{array}{l}\text { Radioimmunoasse } \\
\text { kit }\end{array}$ & $24 / 21$ \\
\hline I. Omar et al. ${ }^{32}$ & 2021 & Egypt & $\begin{array}{l}\text { Patchy, AU, AT, } \\
\text { Ophiasis }\end{array}$ & $72 / 75$ & $5.3^{*}$ & $3.9^{*}$ & ELISA & $\begin{array}{c}\text { Adults: } 37.6 \pm 12 \text {, } \\
\text { Children: } 11 \pm \\
\text { 3.3/ Adults: } 37.4 \\
\pm 13.7 \text {, Children: } \\
12.9 \pm 2.8\end{array}$ \\
\hline Barahmani et al. ${ }^{18}$ & 2009 & USA & $\begin{array}{c}\text { Transient AA, } \\
\text { Persistent AA, AT or } \\
\text { AU }\end{array}$ & $269 / 18$ & $\begin{array}{l}\text { AAP: } 3.58^{*} \\
\text { AAT: } 3.06^{\star} \text { AT } \\
\text { / AU: } 2.97^{*}\end{array}$ & $2.46^{\star}$ & $\begin{array}{l}\text { Mutli-analyte } \\
\text { proteome array }\end{array}$ & $\begin{array}{c}39 \pm 18.8 / 44 \pm \\
13.6\end{array}$ \\
\hline
\end{tabular}




\section{RESULTS}

A total of 1098 articles were found in the aforementioned databases. 629 duplicate papers were excluded. 453 studies were excluded after a review of the titles and abstracts. Finally, 16 studies were selected to be involved. The detailed search process is shown in Figure 1. Extracted data for IL-6, IL-10, and TNF- $\alpha$ are reported in Tables 1 and 2 and Table 3, respectively. The levels of IL-10 in the serum of healthy subjects were higher than AA patients, but the difference was not significant (SMD $=-0.22,95 \% \mathrm{CI}-0.95$ to 0.50 ).

Among six studies that report IL-10 levels in the sera of AA patients, one study shows reduced levels of IL10 in AA patients compared to healthy controls ${ }^{17}$, one study shows a raised level ${ }^{16}$, and four studies show no significant difference ${ }^{14,18,25,26}$. There was a significant elevation of IL- 6 in the serum of AA patients compared to healthy controls (SMD $=1.57,95 \%$ CI 0.17 to 2.97 ).

Among 5 studies that describe IL- 6 levels, three studies show elevated levels of IL-6 in AA patients ${ }^{11,23,24}$, and two studies show no significant difference between AA patients and healthy subjects ${ }^{14,18}$. Significantly elevated levels of TNF- $\alpha$ in the serum of AA patients compared to healthy subjects were found $(\mathrm{SMD}=2.05,95 \%$ CI 0.98 to 3.13$)$.

Among 11 studies that describe TNF- $\alpha$ levels in AA patients and healthy controls, eight studies describe higher levels of TNF- $\alpha$ in AA patients 11,23,25,27-30,32, and no significant difference was seen in three studies ${ }^{15,18,31}$. Forest plots of TNF- $\alpha$, IL-6, and IL-10 are shown in Figures 2 and 3and Figure 4, respectively. The $\mathrm{p}$-values of Begg's tests $(\mathrm{p}=0.014)$ and Egger's tests $(\mathrm{p}=0.021)$ for IL- 6 indicate evidence of publication bias.

\section{DISCUSSION}

Alopecia areata is an autoimmune disorder that causes small patches of baldness on the scalp or/and body, and it is linked to some coexisting autoimmune disorders such as rheumatoid arthritis, vitiligo, and psoriasis ${ }^{33,34}$. The pathogenesis of AA is not completely understood. It seems that it is associated with a complex interplay between genetic susceptibility and immune system function ${ }^{33,35}$. The abnormal levels of pro-inflammatory cytokines (IL- 6 and TNF- $\alpha$ ) and anti-inflammatory cytokine (IL-10) in AA were confirmed by previous documents ${ }^{11,16}$. The present meta-analysis discovers a significant link between AA and the inflammatory markers, with SMD for TNF- $\alpha$ (SMD $=2.05,95 \%$ CI 0.98 to 3.13 ), followed by IL$6(\mathrm{SMD}=1.57,95 \% \mathrm{CI} 0.17$ to 2.97$)$ and then IL-10 $(\mathrm{SMD}=-0.22,95 \% \mathrm{CI}-0.95$ to 0.50$)$.
The molecular mechanisms responsible for these alterations in immune function need to be explored more fully ${ }^{36}$. The objective of this meta-analysis was to collate data from published literature to evaluate the serum TNF- $\alpha$, IL- 6 , and IL-10 levels in patients with AA.

TNF- $\alpha$ is manufactured by a wide range of cells, including immune and non-immune cells, and is considered to be a pro-inflammatory cytokine that has an essential role in the pathogenesis of many inflammatory diseases such as arthritis, rheumatoid, and psoriasis $^{37-39}$. Our meta-analysis shows increased serum levels of TNF- $\alpha$ in AA patients compared to healthy individuals, which was expected due to the nature of AA which seems to be a Th1 dominant autoimmune disease $\mathbf{4 0}$. Hoffmann et al. showed that TNF- $\alpha$ could abrogate hair growth in vitro; it has been found that TNF- $\alpha$ can result in vacuolation of matrix cells in follicle bulbs and can diminish the matrix size ${ }^{41,42}$. Alzolibani et al. showed that mRNA expression of TNF$\alpha$ is higher in PBMC of AA patients than healthy controls $^{30}$. It has been found that lesioned skin biopsies of AA patients have elevated levels of TNF- $\alpha$ in comparison with non-lesioned biopsies or biopsies from healthy controls ${ }^{43}$.

IL-6 is a pro-inflammatory cytokine that plays an important role in the pathogenesis of different autoimmune diseases or chronic inflammatory conditions $\mathbf{4 4}$. This study showed that IL-6 levels are significantly raised in AA patients compared to healthy individuals. Transcript of IL- 6 has been shown to have higher expression in balding dermal papilla cells than nonbalding dermal papilla cells and IL-6 can also inhibit elongation of the hair shaft in a dose-dependent manner ${ }^{45}$. IL-6 levels tend to be elevated in autoimmune diseases regardless of the dominant response; it is elevated in multiple sclerosis patients (Th1 dominant), SLE (TH2 dominant), and psoriasis (in which Th17 plays a crucial role in its pathogenesis). Therefore, elevated levels of IL-6 in AA patients are not unexpected $^{46-51}$.

IL-10 is an anti-inflammatory cytokine, and its dysregulation can increase the chance of autoimmunity ${ }^{52}$. Contrary to our expectations, pooled antiinflammatory IL-10 was not significantly decreased in patients with AA. The literature on AA proposes that IL-10 imperfection might contribute to its pathogenesis ${ }^{\mathbf{1 6}}$. It seems that disequilibrium in cytokine production, with a relative surplus of pro-inflammatory and Th1 types versus anti-inflammatory cytokines, could have a role in the permanence of alopecia lesions ${ }^{53}$. Freyschmidt-Paul et al. found that IL-10 deficient mice are more resistant to the induction of 


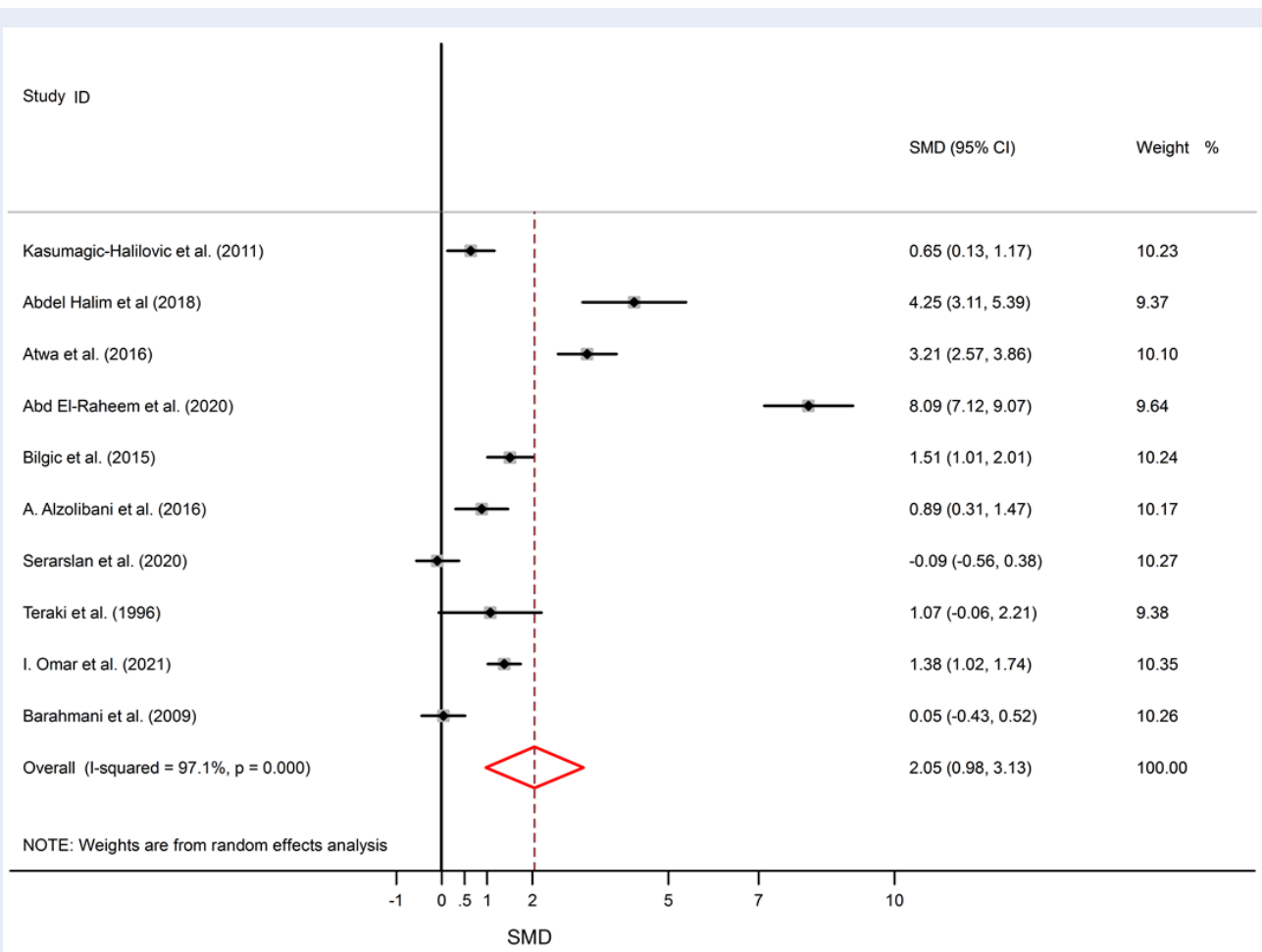

Figure 2: Forest plot of serum TNF- $\alpha$ levels in AA patients and controls. The square represents the point estimate of the effect for each study, and its size is proportional to the weight of this included study. The horizontal line through the square represents the $95 \% \mathrm{Cl}$ around the point estimate. The vertical line is the line of no effect. The diamond represents the pooled standardized mean difference and the width of the diamond represents the 95\% $\mathrm{Cl}$ around this estimate. https://doi.org/10.6084/m9.figshare.16910314.v1

$\mathrm{AA}^{54}$. Hoffman et al. showed increased mRNA levels of IL-10 in AA biopsies after treatment with Diphenylcyclopropenone, and IL-10 transcript levels in untreated biopsies of AA patients were nearly similar to healthy controls ${ }^{55}$.

Altogether, these lines of evidence show that activation of the immune system is one of the biological processes associated with the pathogenesis of AA. Thus, the present study could be worthwhile in providing an evidence pool for future treatment suggestions.

There were a few limitations associated with our metaanalysis. First, insufficient data in some studies was a significant issue in our conducted meta-analysis. Second, due to the inconsistency of the classification methods, the different disease subtypes of AA could not be separately analyzed using the meta-analysis. Third, the limited number of studies may lead to less accurate results in meta-analysis studies. Fourth, publication bias could affect the results of this metaanalysis study.

\section{CONCLUSIONS}

Altogether, these lines of evidence show that activation of the immune system is one of the biological processes which may be associated with the pathogenesis of AA. The present study could be worthwhile in providing an evidence pool for future treatment suggestions. Despite of our findings, we still need further researches with a stronger design to develop knowledge in this regard.

\section{ABBREVIATIONS}

AA: Alopecia areata

IL-6: Interleukin-6

IL-10: Interleukin-10

TNF- $\alpha$ : Tumor Necrosis Factor- $\alpha$

\section{ACKNOWLEDGMENTS}

We wish to appreciate all those who helped us during this study. The authors declare that they did not receive any funding for this study. 


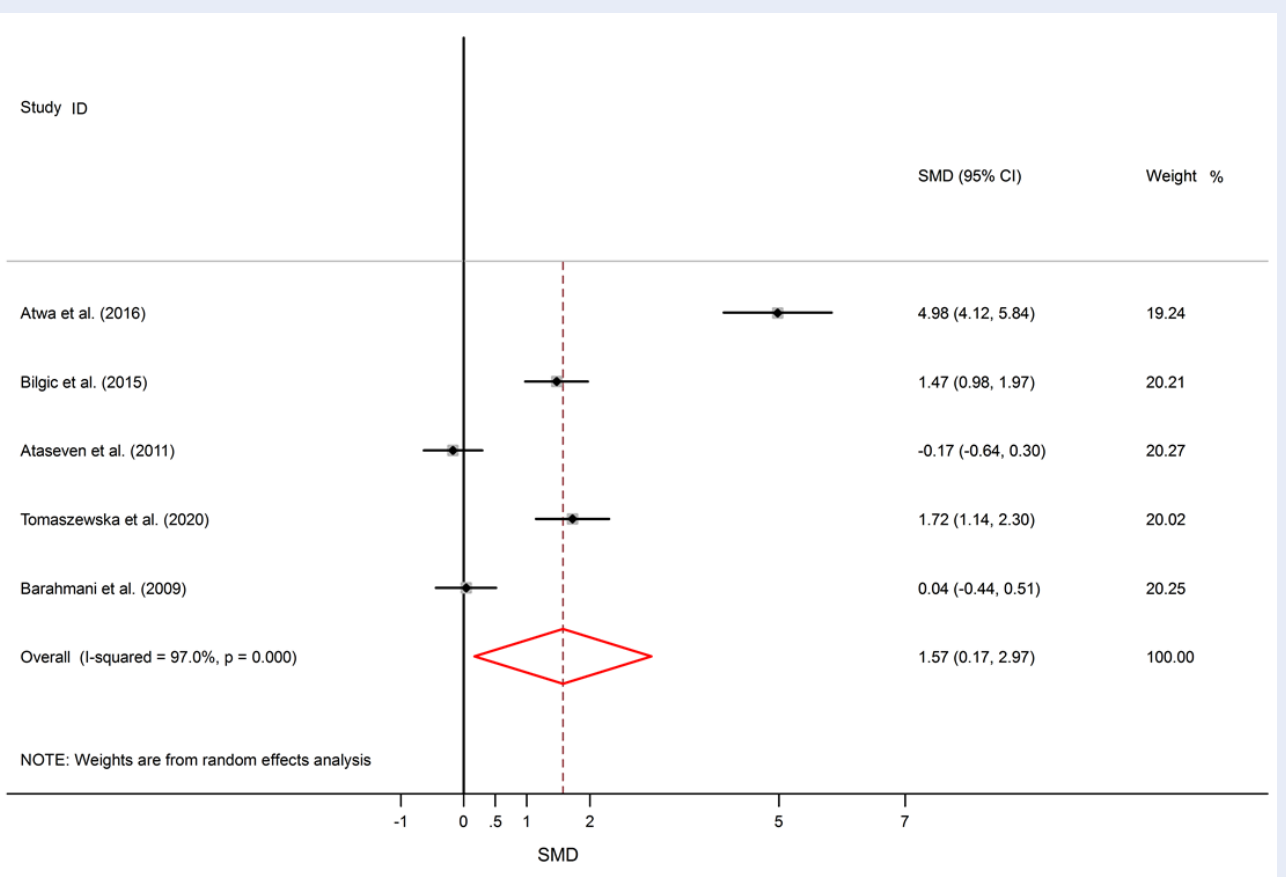

Figure 3: Forest plots of serum IL-6 levels in AA patients and controls. The square represents the point estimate of the effect for each study, and its size is proportional to the weight of this included study. The horizontal line through the square represents the $95 \% \mathrm{Cl}$ around the point estimate. The vertical line is the line of no effect. The diamond represents the pooled standardized mean difference and the width of the diamond represents the $95 \%$ $\mathrm{Cl}$ around this estimate. https://doi.org/10.6084/m9.figshare.16910317.v1

\section{AUTHOR'S CONTRIBUTIONS}

Authors equally contributed to this work. All authors read and approved the final manuscript.

\section{FUNDING}

None.

\section{AVAILABILITY OF DATA AND MATERIALS}

Data and materials used and/or analyzed during the current study are available from the corresponding author on reasonable request.

\section{ETHICS APPROVAL AND CONSENT TO PARTICIPATE}

This study was conducted in accordance with the amended Declaration of Helsinki. The institutional review board approved the study, and all participants provided written informed consent.

\section{CONSENT FOR PUBLICATION}

Not applicable.

\section{COMPETING INTERESTS}

The authors declare that they have no competing interests.

\section{REFERENCES}

1. Wasserman D, Guzman-Sanchez DA, Scott K, McMichael A. Alopecia areata. Int J Dermatol. 2007;46(2):121-31. PMID: 17269961. Available from: 10.1111/j.1365-4632.2007.03193.x.

2. Safavi KH, Muller SA, Suman VJ, Moshell AN, Melton LJ. Incidence of alopecia areata in Olmsted County, Minnesota, 1975 through 1989. Mayo Clin Proc. 1995;70(7):628-33. PMID: 7791384. Available from: 10.4065/70.7.628.

3. Tan E, Tay YK, Goh CL, Giam YC. The pattern and profile of alopecia areata in Singapore - a study of 219 Asians. Int J Dermatol. 2002;41(11):748-53. PMID: 12452996. Available from: 10.1046/j.1365-4362.2002.01357.x.

4. Tan E, Tay YK, Giam YC. A clinical study of childhood alopecia areata in Singapore. Pediatr Dermatol. 2002;19(4):298-301. PMID: 12220271. Available from: 10.1046/j.1525-1470.2002. 00088.x.

5. Ting PT, Barankin B. Patches of hair loss on the scalp. Can Fam Physician. 2006;52(8):957. PMID: 17273496.

6. Medzhitov R. Origin and physiological roles of inflammation. Nature. 2008;454(7203):428-35. PMID: 18650913. Available from: $10.1038 /$ nature 07201 .

7. Wojdasiewicz $P$, Poniatowski LA, Szukiewicz D. The role of inflammatory and anti-inflammatory cytokines in the pathogenesis of osteoarthritis. Mediators of inflammation. 2014:2014:561459. Available from: 10.1155/2014/561459.

8. Pradhan AD, Manson JE, Rifai N, Buring JE, Ridker PM. Creactive protein, interleukin 6 , and risk of developing type 


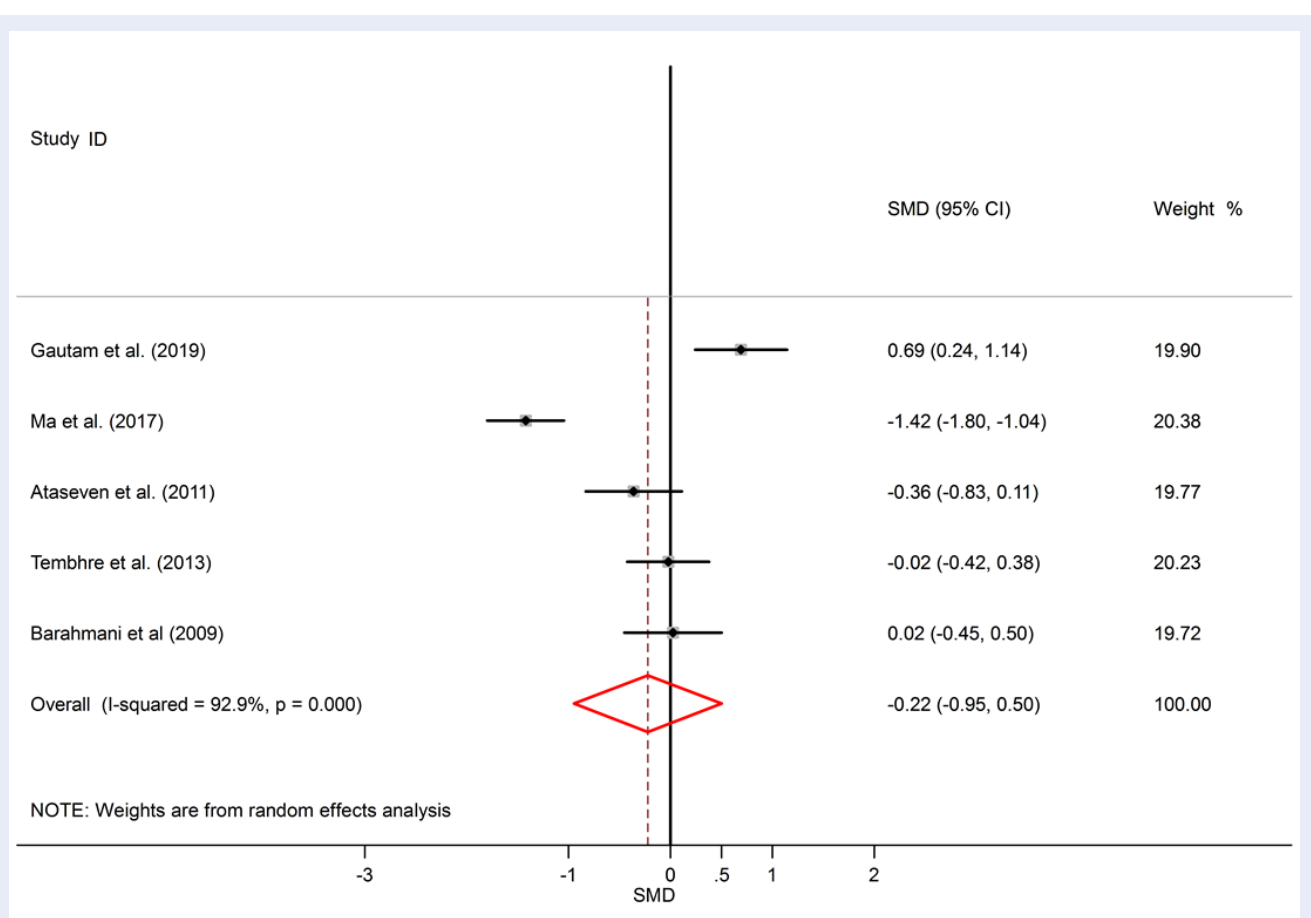

Figure 4: Forest plots of serum IL-10 levels in AA patients and controls. The square represents the point estimate of the effect for each study, and its size is proportional to the weight of this included study. The horizontal line through the square represents the $95 \% \mathrm{Cl}$ around the point estimate. The vertical line is the line of no effect. The diamond represents the pooled standardized mean difference and the width of the diamond represents the 95\% $\mathrm{Cl}$ around this estimate. https://doi.org/10.6084/m9.figshare.16910320.v1

2 diabetes mellitus. JAMA. 2001;286(3):327-34. PMID: 11466099. Available from: 10.1001/jama.286.3.327.

9. Pahwa R, Goyal A, Bansal P, Jialal I. Chronic Inflammation. In StatPearls. StatPearls Publishing, Treasure Island (FL); 2020; 2018.

10. Malemud CJ. Defective JAK-STAT Pathway Signaling Contributes to Autoimmune Diseases. Curr Pharmacol Rep. 2018;4(5):358-66. Available from: 10.1007/s40495-018-01514.

11. Bilgic O, Sivrikaya A, Unlu A, Altinyazar HC. Serum cytokine and chemokine profiles in patients with alopecia areata. J Dermatolog Treat. 2016;27(3):260-3. PMID: 26367497. Available from: 10.3109/09546634.2015.1093591.

12. Li $P$, Zheng $Y$, Chen $X$. Drugs for autoimmune inflammatory diseases: from small molecule compounds to anti-TNF biologics. Front Pharmacol. 2017;8:460. PMID: 28785220. Available from: 10.3389/fphar.2017.00460.

13. Sokolik R, Iwaszko M, Świerkot J, Wysoczańska B, Korman L, Wiland P. Relationship Between Interleukin-6 -174G/C Genetic Variant and Efficacy of Methotrexate Treatment in Psoriatic Arthritis Patients. Pharm Genomics Pers Med. 2021;14:157-66. PMID: 33536774. Available from: 10.2147/ PGPM.S264555.

14. Ataseven A, Saral Y, Godekmerdan A. Serum cytokine levels and anxiety and depression rates in patients with alopecia areata. Eurasian J Med. 2011;43(2):99-102. PMID: 25610172. Available from: 10.5152/eajm.2011.22.

15. Serarslan G, Özcan O, Okyay E, Ünlü B, Karadağ M. Role of adiponectin and leptin in patients with alopecia areata with scalp hair loss. Ir J Med Sci. 2020;190(3):1015-1020. PMID: 33083959. Available from: 10.1007/s11845-020-02410-4.

16. Gautam RK, Singh Y, Gupta A, Arora P, Khurana A, Chitkara A. The profile of cytokines (IL-2, IFN- $\gamma$, IL-4, IL-10, IL-17A and IL-23) in active alopecia areata. J Cosmet Dermatol. 2020;19(1):234-40. PMID: 31087753. Available from: 10.1111/ jocd.12970.

17. Ma X, Chen S, Jin W, Gao Y. Th1/Th2 PB balance and CD200 expression of patients with active severe alopecia areata. Exp Ther Med. 2017;13(6):2883-7. PMID: 28587354. Available from: $10.3892 / \mathrm{etm} .2017 .4312$.

18. Barahmani N, Lopez A, Babu D, Hernandez M, Donley SE, Duvic $M$. Serum T helper 1 cytokine levels are greater in patients with alopecia areata regardless of severity or atopy. Clin Exp Dermatol. 2010;35(4):409-16. PMID: 19874320. Available from: 10.1111/j.1365-2230.2009.03523.x.

19. Peters JP, Hooft L, Grolman W, Stegeman I. Reporting Quality of Systematic Reviews and Meta-Analyses of Otorhinolaryngologic Articles Based on the PRISMA Statement. PLoS One. 2015;10(8):e0136540. PMID: 26317406. Available from: 10.1371/journal.pone. 0136540 .

20. National Heart, Lung, and Blood Institute. Study Quality Assessment Tools [https://www.nhlbi.nih.gov/health-topics/stu dy-quality-assessment-tools].

21. Egger $M$, Smith GD, Schneider $M$, Minder $C$. Bias in meta-analysis detected by a simple, graphical test. BMJ. 1997;315(7109):629-34. PMID: 9310563. Available from: 10.1136/bmi.315.7109.629.

22. Higgins JP, Green S. Cochrane handbook for systematic reviews of interventions. John Wiley \& Sons; 2011.

23. Atwa MA, Youssef N, Bayoumy NM. T-helper 17 cytokines (interleukins 17, 21, 22, and 6, and tumor necrosis factor- $\alpha$ ) in patients with alopecia areata: association with clinical type and severity. Int J Dermatol. 2016;55(6):666-72. PMID: 26235375. Available from: 10.1111/ijd.12808. 
24. Tomaszewska K, KozM, Kaszuba A, Lesiak A, Narbutt J, Zalewska-Janowska A. Increased Serum Levels of IFN- $\gamma$, IL-1 $\beta$, and IL- 6 in Patients with Alopecia Areata and Nonsegmental Vitiligo. Oxid Med Cell Longev. 2020;2020:5693572. PMID: 32832001 . Available from: 10.1155/2020/5693572.

25. Loh SH, Moon HN, Lew BL, Sim WY. Role of Thelper 17 cells and $\mathrm{T}$ regulatory cells in alopecia areata: comparison of lesion and serum cytokine between controls and patients. J Eur Acad Dermatol Venereol. 2018;32(6):1028-33. PMID: 29283462. Available from: $10.1111 /$ jdv.14775.

26. Tembhre MK, Sharma VK. T-helper and regulatory T-cell cytokines in the peripheral blood of patients with active alopecia areata. Br J Dermatol. 2013;169(3):543-8. PMID: 23607748. Available from: 10.1111/bjd.12396.

27. Kasumagic-Halilovic E, Prohic A, Cavaljuga S. Tumor necrosis factor-alpha in patients with alopecia areata. Indian J Dermatol. 2011;56(5):494-6. PMID: 22121261. Available from: 10.4103/0019-5154.87124.

28. Halim DA, Zeid OMA, Rashed L, Saleh MA. Alteration of serum and tissue tumor necrosis factor alpha levels: A possible mechanism of action of oral pulse steroids in the treatment of alopecia areata. J Cosmet Dermatol. 2019;18(4):112832. PMID: 30294905 . Available from: 10.1111/jocd.12795.

29. El-Raheem TA, Mahmoud RH, Hefzy EM, Masoud M, Ismail R, Aboraia NM. Tumor necrosis factor (TNF)- $\alpha-308 \mathrm{G} / \mathrm{A}$ gene polymorphism (rs1800629) in Egyptian patients with alopecia areata and vitiligo, a laboratory and in silico analysis. PLoS One. 2020;15(12):e0240221. PMID: 33370782. Available from: 10.1371/journal.pone.0240221.

30. Alzolibani AA, Rasheed Z, Saif GB, Al-Dhubaibi MS, Robaee AAA. Altered expression of intracellular Toll-like receptors in peripheral blood mononuclear cells from patients with alopecia areata. BBA Clin. 2016;5:134-42. PMID: 27114923. Available from: 10.1016/j.bbacli.2016.03.006.

31. Teraki Y, Imanishi K, Shiohara T. Cytokines in alopecia areata: contrasting cytokine profiles in localized form and extensive form (alopecia universalis). Acta Derm Venereol. 1996;76(6):421-3. PMID: 8982401

32. Omar SI, Hamza AM, Eldabah N, Habiba DA. IFN- $\alpha$ and TNF$\alpha$ serum levels and their association with disease severity in Egyptian children and adults with alopecia areata. Int J Dermatol. 2021;60(11):1397-1404. PMID: 34008204. Available from: 10.1111/ijd.15658.

33. Simakou T, Butcher JP, Reid S, Henriquez FL. Alopecia areata: A multifactorial autoimmune condition. J Autoimmun. 2019;98:74-85. PMID: 30558963. Available from: 10.1016/j. jaut.2018.12.001.

34. Pratt $\mathrm{CH}$, King LE, Messenger AG, Christiano AM, Sundberg JP. Alopecia areata. Nat Rev Dis Primers. 2017;3(1):17011. PMID: 28300084. Available from: 10.1038/nrdp.2017.11.

35. Gregoriou S, Papafragkaki D, Kontochristopoulos G, Rallis E, Kalogeromitros D, Rigopoulos D. Cytokines and other mediators in alopecia areata. Mediators Inflamm. 2010;2010:928030. PMID: 20300578. Available from: 10.1155/2010/928030.

36. Tabara K, Kozłowska M, Jkedrowiak A, Bienias W, Kaszuba A. Serum concentrations of selected proinflammatory cytokines in children with alopecia areata. Postepy Dermatol Alergol. 2019;36(1):63-69. PMID: 30858781. Available from: 10.5114/ ada.2019.82826.

37. Zhang B, Ramesh G, Norbury CC, Reeves WB. Cisplatininduced nephrotoxicity is mediated by tumor necrosis factor$\alpha$ produced by renal parenchymal cells. Kidney Int. 2007;72(1):37-44. PMID: 17396112. Available from: 10.1038/ sj.ki.5002242.

38. Moelants EA, Mortier A, Damme JV, Proost P. Regulation of TNF- $\alpha$ with a focus on rheumatoid arthritis. Immunol Cell Biol. 2013;91(6):393-401. PMID: 23628802. Available from: 10.1038/icb.2013.15.

39. Ogawa E, Sato Y, Minagawa A, Okuyama R. Pathogenesis of psoriasis and development of treatment. J Dermatol. 2018;45(3):264-72. PMID: 29226422. Available from: 10.1111/ 1346-8138.14139.
40. Gilhar A, Kalish RS. Alopecia areata: a tissue specific autoimmune disease of the hair follicle. Autoimmun Rev. 2006;5(1):64-9. PMID: 16338213. Available from: 10.1016/j. autrev.2005.07.001.

41. Hoffmann R, Eicheler W, Huth A, Wenzel E, Happle R. Cytokines and growth factors influence hair growth in vitro. Possible implications for the pathogenesis and treatment of alopecia areata. Arch Dermatol Res. 1996;288(3):153-6. PMID: 8967784. Available from: 10.1007/BF02505825.

42. Philpott MP, Sanders DA, Bowen J, Kealey T. Effects of interleukins, colony-stimulating factor and tumour necrosis factor on human hair follicle growth in vitro: a possible role for interleukin-1 and tumour necrosis factor- $\alpha$ in alopecia areata. Br J Dermatol. 1996;135(6):942-8. PMID: 8977716. Available from: 10.1046/j.1365-2133.1996.d01-1099.x.

43. El-Tahlawi SR, El-Hanafy GM, El-Rifaie AE, Shaker OG. Assessment of the level of tumor necrosis factor- $\alpha$ in localized alopecia areata. Journal of the Egyptian Women's Dermatologic Society. 2013;10(2):81-4. Available from: 10.1097/01.EWX $0000427503.58962 .9 \mathrm{e}$.

44. Yang DH. The Biological Effects of Interleukin- 6 and Their Clinical Applications in Autoimmune Diseases and Cancers. Rheumatica Acta: Open Access. 2017;1(1):6-16. Available from: https://www.peertechzpublications.com/articles/RAOA1-103.php.

45. Kwack MH, Ahn JS, Kim MK, Kim JC, Sung YK Dihydrotestosterone-inducible IL-6 inhibits elongation of human hair shafts by suppressing matrix cell proliferation and promotes regression of hair follicles in mice. J Invest Dermatol. 2012;132(1):43-9. PMID: 21881585. Available from: 10.1038/jid.2011.274

46. Stelmasiak Z, Kozioł-Montewka M, Dobosz B, Rejdak K, Bartosik-Psujek H, Mitosek-Szewczyk K. Interleukin-6 concentration in serum and cerebrospinal fluid in multiple sclerosis patients. Med Sci Monit. 2000;6(6):1104-8. PMID: 11208463.

47. Ripley BJ, Goncalves B, Isenberg DA, Latchman DS, Rahman A. Raised levels of interleukin 6 in systemic lupus erythematosus correlate with anaemia. Ann Rheum Dis. 2005;64(6):849-53. PMID: 15897306. Available from: 10.1136/ard.2004.022681.

48. Ishida H, Ota H, Yanagida H, Dobashi H. An imbalance between Th1 and Th2-like cytokines in patients with autoimmune diseases-differential diagnosis between Th1 dominant autoimmune diseases and Th2 dominant autoimmune diseases. Jpn J Clin Med. 1997;55(6):1438-43. PMID: 9200929.

49. Li B, Huang L, Lv P, Li X, Liu G, Chen Y. The role of Th17 cells in psoriasis. Immunol Res. 2020;68(5):296-309. PMID: 32827097. Available from: 10.1007/s12026-020-09149-1.

50. Fitch E, Harper E, Skorcheva I, Kurtz SE, Blauvelt A. Pathophysiology of psoriasis: recent advances on IL-23 and Th17 cytokines. Curr Rheumatol Rep. 2007;9(6):461-7. PMID: 18177599. Available from: 10.1007/s11926-007-0075-1.

51. Oliveira PS, Cardoso PR, Lima EV, Pereira MC, Duarte AL, Pitta ID, et al. IL-17A, IL-22, IL-6, and IL-21 Serum Levels in PlaqueType Psoriasis in Brazilian Patients. Mediators Inflamm. 2015;2015:819149. PMID: 26351408. Available from: 10.1155/ 2015/819149.

52. Iyer SS, Cheng G. Role of interleukin 10 transcriptional regulation in inflammation and autoimmune disease. Crit Rev Immunol. 2012;32(1):23-63. Available from: 10.1615/ CritRevImmunol.v32.i1.30.

53. Bodemer C, Peuchmaur M, Fraitaig S, Chatenoud L, Brousse N, Prost YD. Role of cytotoxic T cells in chronic alopecia areata. J Invest Dermatol. 2000;114(1):112-6. PMID: 10620125. Available from: 10.1046/j.1523-1747.2000.00828.x.

54. Freyschmidt-Paul P, McElwee KJ, Happle R, Kissling S, Wenzel E, Sundberg JP. Interleukin-10-deficient mice are less susceptible to the induction of alopecia areata. J Invest Dermatol. 2002;119(4):980-2. PMID: 12406350. Available from: 10.1046/j.1523-1747.2002.00230.x.

55. Hoffmann R, Wenzel E, Huth $A$, van der Steen $P$, Schäufele $M$, Henninger HP. Cytokine mRNA levels in Alopecia areata be- 
fore and after treatment with the contact allergen diphenylcyclopropenone. J Invest Dermatol. 1994;103(4):530-3. PMID:
7930677. Available from: 10.1111/1523-1747.ep12395722. 
Ready to submit your manuscript? Choose Biomedpress and benefit from:

- Fast, convenient online submission

- Through peer-review by experienced researchers

- Rapid publication on acceptance

- Free of charge (without publication fees)

Learn more http://www.biomedpress.org/journals/
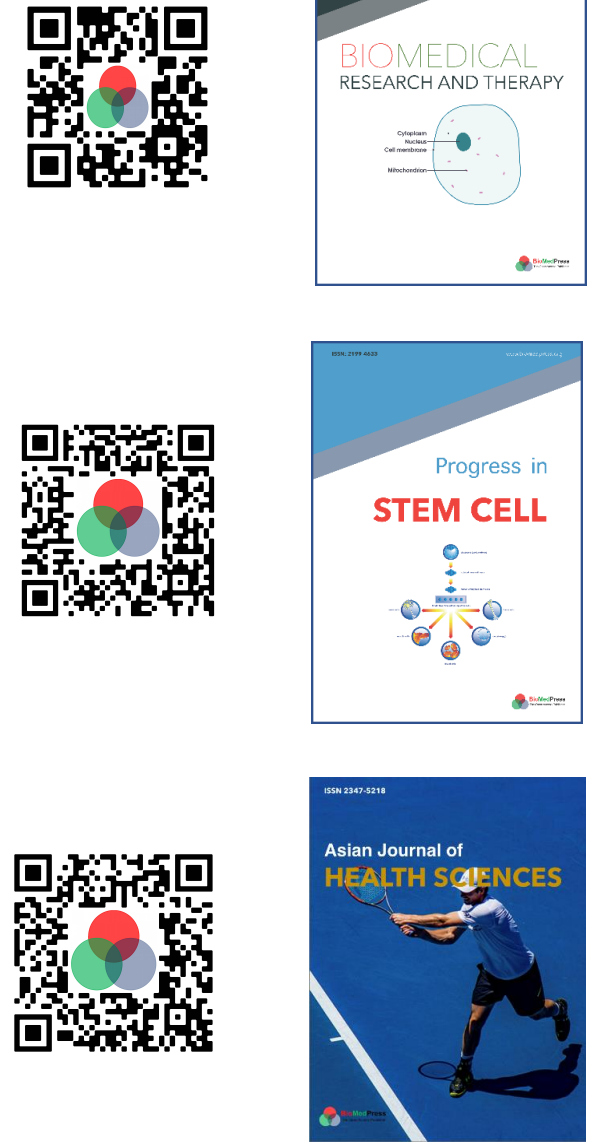

Asian Journal of Health Sciences

ISSN: 2347-5218

Indexed: Google Scholar

Acceptance Rate (2020): 72.89\%

Article Publishing Charge: Free

Submission to first editorial decision: 16.5 days

Biotechnological Research

ISSN: 2395-6763

Indexed: Google Scholar

Acceptance Rate (2020): $67.02 \%$

Article Publishing Charge: Free

Submission to first editorial decision: 28.5 days 